\title{
Simulação e/ou dissimulação: reflexão sobre a estética em Memórias póstumas de Brás Cubas e As visitas do Dr. Valdez
}

\author{
Natalino da Silva de Oliveira *
}

\begin{abstract}
Resumo
O objetivo deste artigo é trabalhar com o conceito de Estética da dissimulação abordando-o teoricamente e de maneira prática. Pragmaticamente, será feita uma análise de duas personagens: Prudêncio e Vicente. A primeira personagem está presente no livro Memórias póstumas de Brás Cubas e a segunda é uma das protagonistas do romance As visitas do Dr. Valdez. A pesquisa deste conceito parte de uma provocação proveniente da leitura do ensaio Pode o subalterno falar?, de Gayagri C. Spivak e alcança, como base para a formulação de uma possível resposta, o livro A cena em sombras, de Leda Maria Martins.

Palavras-chave: Literatura afro-brasileira. Subalternidade. Estética da dissimulação.
\end{abstract}

\section{A voz subalterna}

Y es tanta la tiranía

De esta disimulación Que aunque de raros anhelos

Se me hincha el corazón,

Tengo miradas de reto

Y voz de resignación.

(REYES, 1959, p. 67).

O objetivo deste artigo é trabalhar com o conceito de "Estética da dissimulação" abordando-o teoricamente e de maneira prática. Pragmaticamente, será feita uma análise de duas personagens: Prudêncio e Vicente. A primeira personagem está presente no livro Memórias póstumas de Brás Cubas (1999) e a segunda é uma das protagonistas do romance

* Universidade Federal de Minas Gerais - UFMG. 
As visitas do Dr. Valdez (2004). Para tanto, faz-se necessária uma breve explanação desta variedade estética.

A pesquisa deste conceito parte de uma provocação proveniente da leitura do ensaio Pode o subalterno falar? (2010). Neste livro, Spivak levanta a questão da existência de uma voz subalterna e da possibilidade desta de ser ouvida. Até hoje, a resposta passa por formulações complexas. Neste momento, não refletirei muito sobre a questão - algo que já fiz em textos anteriores. Acelerarei a resposta dizendo que sim, é possível para o subalterno falar e também é possível que sua voz seja ouvida. Entretanto, o caminho para que isto ocorra passa, necessariamente, pela arte, pela estética e, principalmente, pela subversão. Porém, a ação subversiva que pretendo estudar não se dá de forma direta. Ela ocorre de forma sutil - é o que estou denominando como Estética da dissimulação.

A Estética da dissimulação ocorre em contextos bem específicos de dominação. Nessas situações a estética não funciona somente como um meio de sensibilizar e humanizar as pessoas. Ela funciona mesmo como meio de sobreviver e de existir. Dessa forma ela se aproxima muito da Estética da existência, pensada por Foucault. A também nomeada Estilística existencial deveria ser empregada no plural para exprimir corretamente sua multiplicidade de forma.

Foucault utiliza, juntamente com ela, os conceitos de forma, estilo, arte, beleza. Essa denominação estética aparece na Introdução ao segundo volume de História da sexualidade: o uso dos prazeres (1984), em momento em que seu autor se preocupa com a problematização moral. Diante dessa questão complexa, ele, assim com Nietzsche, vai buscar, nas características da cultura Greco-latina, nos escritos epicuristas e estóicos, o caminho que deveria seguir. Assim ele chega à interessante constatação de que a arte estava profundamente ligada à existência (artes da existência) e proporcionava ao indivíduo o controle, a governabilidade de si.

Há todo um processo em que o que é mais comum de ocorrer é a passagem da simulação para a dissimulação. Sem apropriar-se das estratégias de dominação utilizadas por aqueles que o oprimem se tornaria impossível ao oprimido vencer as limitações impostas. Por isso é necessário simular, aprender simulando, repetir. Tal como ocorre quando alguém está tentando dominar uma língua estrangeira. Assim também ocorre com aquele que quer sair da condição de subalterno ou, pelo menos, ter uma voz que seja verdadeiramente ouvida: o primeiro momento é de repetição. É preciso dominar todo um conjunto de 
códigos e de seus significados e só há uma forma de apreendê-los: repetindo, repetindo, até que ocorra a assimilação. E afinal, o que é prestígio/ou poder, senão o domínio aceitável de um conjunto de códigos que façam com que o indivíduo seja respeitado ou tenha sua voz ouvida.

É dessa forma que Octavio Paz observará a realidade cultural mexicana. O povo mexicano, assim como todos os povos das Américas, foi formado pelo processo traumático da colonização. Neste processo, o povo indígena, ou autóctone, sofreu demasiadamente com as mais variadas formas de violência. Este fato histórico marcará profundamente o modo de ser e de agir deste povo.

Entretanto, como foi afirmado no início, o primeiro processo de defesa que se passa é o de simulação, o de cópia dos modelos considerados de prestígio. Assim, o indivíduo na condição de subalterno, passa a ser um espelho que reflete as atitudes de classes dominantes. Em muitos casos ela se torna um hábito tão arraigado culturalmente que passa a fazer parte da própria identidade. Nestes casos, fica complicada a passagem do estágio simulador para o estágio dissimulador.

La simulación, que no acude a nuestra pasividad, sino que exige una invención activa y que se recrea a sí misma a cada instante, es una de nuestras formas de conducta habituales. Mentimos por placer y fantasía, sí, como todos los pueblos imaginativos, pero también para ocultarnos y ponernos al abrigo de intrusos. (PAZ, 2000, p. 44). ${ }^{1}$

Este processo exige o dinamismo constante para que se dê de forma efetiva. O simulador deve atualizar-se constantemente para que não se apresente equivocadamente e seja ridicularizado. Este estágio é importante para que o processo evolua para algo superior. Toda esta evolução evoca elementos artísticos atrelados a valores culturais. Nesta busca por ser o que verdadeiramente não é, o simulador passa a fazer arte - uma arte de sobrevivência, necessária, indispensável. O improvisar constante exige uma ação performativa incansável - um constante desafio de sobrevivência.

El simulador pretende ser lo que no es. Su actividad reclama una constante improvisación, un ir hacia adelante siempre, entre arenas movedizas. A cada minuto hay que rehacer,

\footnotetext{
1 A simulação, que não vem de nossa passividade, mas ao contrário exige uma invenção ativa e que se recria a si mesma a cada instante, é uma de nossas formas de conduta habituais. Mentimos por prazer e fantasia, sim, como todos os povos imaginativos, mas também, para ocultar-nos e colocar-nos ao abrigo de intrusos. (PAZ, 2000, p. 44)
} 
recrear, modificar el personaje que fingimos, hasta que llega un momento en que realidad y apariencia, mentira y verdad, se confunden. De tejido de invenciones para deslumbrar al prójimo, la simulación se trueca en una forma superior, por artística, de la realidad. Nuestras mentiras reflejan, simultáneamente, nuestras carencias y nuestros apetitos, lo que no somos y lo que deseamos ser. Simulando, nos acercamos a nuestro modelo y a veces el gesticulador, como ha visto con hondura Usigli, se funde con sus gestos, los hace auténticos. (PAZ, 2000, p. 44). ${ }^{2}$

Esclavos, siervos y razas sometidas se presentan siempre recubiertos por una máscara, sonriente o adusta ${ }^{3}$. (PAZ, 2000, p. 78). Só que em algumas situações, a simulação precisa ocorrer de forma muito intensa. Para que o individuo seja realmente ator de suas ações, ele precisa atuar. O sofrimento surge no momento em que o simulador alcança o auge do processo (momento em que ele pode avançar para o estágio de dissimulação ou não) e a máscara quase que se funde em seu ser - a observação e repetição o levaram a perfeccionar tanto suas atitudes que já é possível improvisar - o estágio do "ser como" (este estágio será facilmente identificado nas ações da personagem Vicente). Ainda neste momento, o simulador possui real consciência de sua situação, de sua condição e de sua identidade. Ele (ainda que mimetizando todos os gestos) reconhece sua condição de espelho

La simulación es una actividad parecida a la de los actores y puede expresar-se en tantas formas como personajes fingimos. Pero el actor, si lo es de veras, se entrega a su personaje y lo encarna plenamente, aunque después, terminada la representación, lo abandone como su piel la serpiente. El simulador jamás se entrega y se olvida de sí, pues dejaría de simular si se fundiera con su imagen. Al mismo tiempo, esa ficción se convierte en una parte inseparable - y espuria - de su ser: está condenado a representar toda su vida, porque entre su personaje y él se ha establecido una complicidad que nada

2 O simulador pretende ser o que não é. Sua atividade reclama uma constante improvisação, um ir adiante sempre, entre areias movediças. A cada minuto é precisa refazer, recriar, modificar o personagem que fingimos, até que chega um momento em que realidade e aparência, mentira e verdade, se confundem. De tecido de invenções para deslumbrar ao próximo, a simulação se transforma numa forma superior, por artística, da realidade. Nossas mentiras refletem, simultaneamente, nossas carências e nossos apetites, o que não somos e o que desejamos ser. Simulando, nos aproximamos de nosso modelo e às vezes o gesticulador, com já observou com profundidade Usigli, se funde com seus gestos, os faz autênticos. (PAZ, 2000, p. 44).

3 Escravos, servos e raças subjugadas se apresentam sempre cobertos por uma máscara, sorridente ou séria. 
puede romper, excepto la muerte o el sacrificio. La mentira se instala en su ser y se convierte en el fondo último de su personalidad. (PAZ, 2000, p. 46)

Simular está relacionado à capacidade do ser em esquivar-se de sua condição utilizando para isso somente sua astúcia. É uma arte de engano. É dominando esta arte que o indivíduo alcança a governabilidade, a possibilidade de sobreviver abandonar sua identidade. Assim, ele passa para o segundo estágio: a dissimulação (o termo não está sendo utilizado aqui com sua carga de negatividade, dissimular é sobreviver sem deixar de ser). A dissimulação é o estágio posterior à simulação. Dissimular é não chamar a atenção, é não chocar. Deste modo, é possível ocupar lugares, assumir posições. Isso só ocorre, pois o dissimulador (aparentemente) não coloca em perigo o status quo social.

Simular es inventar o, mejor, aparentar y así eludir nuestra condición. La disimulación exige mayor sutileza: el que disimula no representa, sino que quiere hacerse invisible, pasar inadvertido - sin renunciar a su ser - . El mexicano excede en el disimulo de sus pasiones y de sí mismo. Temeroso de la mirada ajena, se contrae, se reduce, se vuelve sombra y fantasma, eco. No camina, se desliza; no propone, insinúa; no replica, rezonga; no se queja, sonríe; hasta cuando canta - si no estalla y se abre el pecho - lo hace entre dientes y a media voz, disimulando su cantar (...) (PAZ, 2000, p.46-47).

É adaptando-se a este modo de viver que surge a Estética da dissimulação. Ela se organiza como uma guerrilha. Apropria-se das matrizes culturais de prestígio (matrizes europeias), aquelas que são de uso da classe dominante. Esta estratégia funciona como um cavalo de Tróia. O dissimulado reconhece que a única forma de sobreviver à dominação alheia é aprendendo a língua daquele que o subjuga. Além disso, ele também reconhece que a luta direta só trará mais dor e sofrimento. Por isso, ele caminha pelo sensível, pela arte de dissimular. Quanto mais aprofunda em sua arte, mais complexa esta se torna e também mais dissimuladora. A arte de apossar-se das armas dos outros para ter condições de lutar. Semelhante à estratégia do jabuti: "O jabuti que só possuía uma casca branca e mole deixou-se morder pela onça que o atacava. Morder tão fundo que a onça ficou pregada no jabuti e acabou por morrer. Do crânio da onça o jabuti fez seu escudo". (CALLADO, 1967, p. 287)

Após a explanação do conceito de Estética da dissimulação, resta associálo a uma representação artística específica. Isso será feito nos próximos tópicos com a literatura por meio de dois romances: Memórias póstumas de Brás Cubas e As visitas do Dr. Valdez. 


\section{A estética da dissimulação em Memórias póstumas de Brás Cubas e As visi- tas do Dr. Valdez}

A estética presente nestes dois romances apresenta uma forma específica, pois está caracterizada por um contexto de dominação também bem específico. O enredo está marcado pela discriminação social e cultural provocada por diferenças físicas - de cor. Os caracteres que estão mais próximos da matriz de origem europeia são mais valorizados.

As duas personagens que este trabalho se propõe analisar são subjugadas pela cor da pele - são negras. E o processo mais marcante para as duas foi o de privação de liberdade provocado pela escravidão.

É preciso ficar-se atento, ouvido apurado, capaz de captar ou os ecos de gritos que povoaram os dolorosos porões das galeras; ou o estalar do chicote, fina cobra, a cobrar o silenciamento e a não-revolta; ou os cantos entoados nas roças de café, açucar ou algodão nas Américas. (MARTINS, 1995, p. 15).

Esses ecos refletem, na identidade, nas atitudes do indivíduo tanto no meio público quanto no privado.

\section{Prudêncio: o simulador}

Memórias póstumas de Brás Cubas foi escrito no primeiro momento como folhetim e saiu na Revista Brasileira de março a dezembro de 1880. Foi publicado como livro no ano seguinte pela Tipografia Nacional. É marcado por temas fortes como a escravidão, as relações entre classes sociais, o cientificismo e o positivismo. A filosofia surge com a apresentação de uma nova corrente filosófica - o humanitismo (que faz referência à dialética do senhor e do escravo de Hegel, à lei do mais forte de "Ao vencedor as batatas," síntese do humanitismo) criado por Joaquim Borba dos Santos (Quincas Borba,que aprofundará o tema em romance posterior Quincas Borba de 1891). A narrativa também é considerada precursora de elementos do Modernismo e do realismo mágico/fantástico de escritores do boom latinoamericano, tais como Jorge Luis Borges, Julio Cortázar, Gabriel Garcia Marquez e outros.

O caráter fortemente crítico da obra para com a sociedade patriarcal e escravocrata da época se apresenta no espelho da elite que é metaforicamente o próprio Brás. Para este grupo de "senhores" do século XVIII - seleto grupo de 
leitores e leitoras de Machado de Assis - rir de Brás Cubas é rir-se da própria desgraça, rir-se de si mesmo. Ainda que tenha um capítulo com especial menção à condição da personagem principal (que pode ser ampliada para o que esta personagem representa, ou seja, a elite escravocrata) - o capítulo "Das negativas", todo o livro é composto de negativas, de não realizações:

Este último capítulo é todo de negativas. Não alcancei a celebridade do emplasto, não fui ministro, não fui califa, não conheci o casamento. Verdade é que, ao lado dessas faltas, coube-me a boa fortuna de não comprar o pão com o suor do meu rosto. Mais; não padeci a morte de $\mathrm{D}$. Plácida, nem a semidemência do Quincas Borba. Somadas umas coisas e outras, qualquer pessoa imaginará que não houve míngua nem sobra, e conseguintemente que saí quite com a vida. E imaginará mal; porque ao chegar a este outro lado do mistério, achei-me com um pequeno saldo, que é a derradeira negativa deste capítulo de negativas: - Não tive filhos, não transmiti a nenhuma criatura o legado da nossa miséria. (ASSIS, 1999, p. 251).

O vazio, a monotonia e a melancolia estão presentes em cada linha do livro. Até mesmo a busca de Brás Cubas por um emplasto capaz de acabar com a melancolia é vazia, pois é impulsionada por um desejo não de simplesmente ajudar as pessoas que sofrem deste mal, mas sim de engrandecer a figura do próprio Brás e da família Cubas. O nome e a aparência para esta família é muito valorizado e considerado o que há de mais importante (o que lembra um pouco o conto de Machado de Assis - "Teoria do medalhão").

A vida de caprichos do jovem Brás Cubas e a de vazio melancólico do velho Brás estão presentes tanto no enredo da obra quanto em seu projeto literário. A própria forma narrativa é conduzida de forma que o leitor fique a mercê deste escritor/narrador com fidúcias da elite brasileira, além de rabugento e cheio de vontades: "A obra em si mesma é tudo: se te agradar, fino leitor, pago-me da tarefa; se te não agradar, pago-te com um piparote, e adeus." (prólogo de Memórias póstumas de Brás Cubas - intitulado “Ao leitor").

A concretização destes desejos sórdidos (vontades) é o motor que move a narrativa e é também a engrenagem mestra das ações da personagem principal, representante metonímica da classe senhorial. Assim, Brás usa e abusa de sua condição para ter tudo o que deseja. Tendo ainda submetidos às suas vontades as pessoas de classes "inferiores", seus dependentes, economicamente ou culturalmente. 
Com sarcasmo o narrador cria uma situação fantasiosa e faz a suposição que se Dona Plácida falasse no momento de seu nascimento diria:

- Aqui estou. Para que me chamastes? E o sacristão e a sacristia naturalmente lhe responderiam: - Chamamos-te para queimar os dedos nos tachos, os olhos na costura, comer mal, ou não comer, andar de um lado para outro, na faina, adoecendo e sarando, com o fim de tornar a adoecer e sarar outra vez, triste agora, logo desesperada, amanhã resignada, mas sempre com as mãos no tacho e os olhos na costura, até acabar um dia na lama ou no hospital; foi para isso que te chamamos, num momento de simpatia. (ASSIS, 1999, p. 159).

A situação de D. Plácida não é diferente da vivida por qualquer agregado e comparada até mesmo à condição do escravo. Viver para servir e servir para viver - um círculo vicioso que se repete como uma espécie de herança de geração para geração.

É assim que Brás Cubas usa Dona Plácida para acobertar a relação com sua amante Virgília. O protagonista suborna a velha beata pobre com cinco conto de réis para que esta assuma o papel de moradora de uma pequena casa na Gamboa, casa esta que era utilizada pelos amantes para seus encontros. Também é assim que ele usa o moleque Prudêncio como cavalo e brinquedo durante a infância e durante a idade adulta sendo considerado "homem livre", o ex-escravo continua seguindo as ordens do senhor.

Sendo assim, a narrativa machadiana atualiza, de forma irônica, os processos em que nosso país foi formado, suas contradições e desmandos que ainda estão presentes. Sua pena desfere duros golpes na sociedade escravocrata. Faz isto de forma dissimulada e indireta - disfarçando suas reais intenções.

Sua obra está marcada pela originalidade apresentada no romance pela incompletude, pelo estilo fragmentário, pela dubiedade e veia cômico-trágicairônica do narrador e pela intervenção direta com o leitor (quase sempre invasiva). Com estas características ${ }^{4}$ o estilo machadiano rompe com o realismo de Flaubert, marcado pela tentativa de neutralidade do narrador, e com o naturalismo de Zola, que buscava retratar a realidade com total objetividade do escritor. Tal como explica o autor: "Há na alma deste livro, por mais risonho que pareça, um sentimento amargo e áspero, que está longe de vir dos seus modelos. É taça que pode ter lavores de igual escola, mas leva outro vinho. Não digo mais para não

4 "recursos criativos destinados a abalar várias das convenções vigentes na prosa de ficção da época" 
entrar na crítica de um defunto, que se pintou a si e a outros, conforme lhe pareceu melhor e mais certo". (ASSIS, 1899, prólogo da $4^{\text {a }}$ edição).

Feitas as observações necessárias sobre o romance, é crucial voltar os olhos para o objetivo primordial deste artigo - as personagens em situações de subalternidade e de modo particular: a personagem Prudêncio.

Prudêncio é o "moleque" da casa, tratado como um simples objeto, um joguete que serve somente como passatempo para o menino Brás. Possui pequenas aparições exparsas ao longo da obra nos capítulos XI, XXV, XLVI e LXVII - por sua vez esta última aparição é a mais cômica e significativa de todas. É personagem secundária do romance, até mesmo por sua condição subalterna. Entretanto, nesta pesquisa, é personagem de maior interesse e isto se dá exatamente pela condição de estar submetido, a todo tempo, à voz senhorial - no início da narrativa por sua condição de escravo e posteriormente, já "homem livre".

Prudêncio também pode representar um projeção irônica, crítica e sarcástica, porém bastante realista, da situação do negro na condição futura de ex-escravo. Este ser, que não é escravo muito menos senhor, ainda viveria por muito tempo à sombra do senhor, tentando em vão imitá-lo e continuando a obedecê-lo por força da repetição e da tradição, fato que também poderá ser observado no momento de análise da personagem de As visitas do Dr. Valdez.

Neste tópico do trabalho a tentativa empreendida será a de provar, por meio de ações e características apresentadas pelo narrador, que Prudêncio assume o papel de simulador. Como já mencionado anteriormente a simulação é o processo que se dá no primeiro estágio das estratégias de sobrevivência e de se fazer ouvir utilizadas pelo indivíduo subalterno. Ocorre que a personagem aqui analisada não consegue ultrapassar esta condição por força de ações tantas vezes repetidas que acabam gerando uma tradição de subserviência.

É no capítulo intitulado "O menino é pai do homem" que Brás ainda criança aprende as primeiras lições de fidúcias de homem representante da elite neste momento conhecemos Prudêncio. E é exatamente neste capítulo que é possível observar a importância do subalterno neste processo de formação da elite. É no trato com a escrava que Brás usa e abusa de suas vontades e por mero capricho foge de suas responsabilidades e culpa justamente aquela que seria a vítima. Já no trato com Prudêncio, o protagonista faz mais, além de aprender a ser senhor ensina o escravo a tradição servir por meio da mera repetição de ações. Quebrando a cabeça da escrava e agredindo o escravo 
reduzindo-o a condição de animal, Brás recebera a alcunha de "menino diabo". Entretando, observa-se a total passividade dos pais que consideram as traquinagens do menino como atitudes normais.

(...) um dia quebrei a cabeça de uma escrava, porque me negara uma colher do doce de coco que estava fazendo, e, não contente com o malefício, deitei um punhado de cinza ao tacho, e, não satisfeito da travessura, fui dizer à minha mãe que a escrava é que estragara o doce "por pirraça"; e eu tinha apenas seis anos. Prudêncio, um moleque de casa, era o meu cavalo de todos os dias; punha as mãos no chão, recebia um cordel nos queixos, à guisa de freio, eu trepava-lhe ao dorso, com uma varinha na mão, fustigava-o, dava mil voltas a um e outro lado, e ele obedecia, algumas vezes gemendo, - mas obedecia sem dizer palavra, ou, quando muito, um - "ai, nhonhô!" - ao que eu retorquia: - "Cala a boca, besta!" (ASSIS, 1999, p. 54).

A aprendizagem do menino prossegue por meio da observação. É em um jantar que, estando reunida a seleta sociedade brasileira - "o juiz-de-fora, três ou quatro oficiais militares, alguns comerciantes e letrados, vários funcionários da administração" (ASSIS, 1999, p.59) -, que o ensino prossegue. Em clima de total descontração, Brás ouve a conversa dos adultos que falam sobre banalidades e entre estas está o assunto de compra e negociação escravos tratado como cotidianidade, efemérides sem nenhuma importância - ou com mera importância financeira.

Um sujeito, ao pé de mim, dava a outro notícia recente dos negros novos que estavam a vir, segundo cartas que recebera de Luanda, uma carta em que o sobrinho lhe dizia ter já negociado cerca de quarenta cabeças, e outra carta em que... Trazia-as justamente na algibeira mas não as podia ler naquela ocasião. O que afiançava é que podíamos contar, só nessa viagem, uns cento e vinte negros, pelo menos. (ASSIS, 1999, p. 60)

Assim, por meio da repetição e da observação, em momento posterior a cena se repete como um désajà- $v u$. Agora, o menino fez-se homem e, na condição de senhor, as traquinagens executadas enquanto menino se tornam coisas sérias, atos de adulto pelos quais ele repete as ações observadas. A negociação da divisão da herança envolve a posse de um escravo com a maior naturalidade. $\mathrm{O}$ ser humano é dividido da mesma forma como são divididos objetos quaisquer.

- Ora, mano, deixe-se dessas coisas, disse Sabina, erguendo-se do sofá; podemos arranjar tudo em 
boa amizade, e com lisura. Por exemplo, o Cotrim não aceita os pretos, quer só o boleeiro de papai e o

Paulo...

- O boleeiro não, acudi eu; fico com a sege e não hei de ir comprar outro.

- Bem, fico com o Paulo e o Prudêncio.

- O Prudêncio está livre.

- Livre?

- Há dois anos.

- Livre? Como seu pai arranjava estas coisas cá por casa, sem dar parte a ninguém! Está direito.

Quanto à prata... creio que não libertou a prata?

(ASSIS, 1999, p. 118).

É também por meio da repetição e da observação que o ex-escravo assume a posição de "homem livre" livre da escravidão formal, mas não da servidão cultural e da situação de subalternidade. É macaqueando que Prudêncio repete quase que literalmente as ações do menino Brás, enquanto este o fazia de cavalo. Brás observa uma cena e no primeiro momento se sente surpreso com um acontecimento tão bizarro. Porém, logo depois, reconhece na cena um reflexo de suas próprias ações do passado - Prudêncio, na condição de homem livre e senhor de escravos, estava repetindo as ações que sofrera com Brás no passado:

Tais eram as reflexões que eu vinha fazendo, por aquele Valongo fora, logo depois de ver e ajustar a casa. Interrompeumas um ajuntamento; era um preto que vergalhava outro na praça. $\mathrm{O}$ outro não se atrevia a fugir; gemia somente estas únicas palavras:

- "Não, perdão meu senhor; meu senhor, perdão!" Mas o primeiro não fazia cada súplica, respondia com uma vergalhada nova.

- Toma, diabo! dizia ele; toma mais perdão, bêbado!

- Meu senhor! gemia o outro.

Cala a boca, besta! replicava o vergalho.

(ASSIS, 1999, p. 150).

Brás percebe que o verganho era o seu cavalo, o moleque da casa, seu joguete de infância, que agora na condição de senhor repete suas ações. Prudêncio simula ser aquilo que verdadeiramente não é. Esta simulação é tão forte que ele sem ao menos perceber, repete inconscientemente as mesma ações que ocorreram no passado - só que agora ele passa da condição de vítima para a de algoz, da condição de escravo para a de "senhor". Um senhor, porém, 
ao avesso que na condição de "homem livre" continua pedindo benção a seu nhonhô do passado e seguindo suas ordens.

- É sim, nhonhô.

- Fez-te alguma cousa?

- É um vadio e um bêbado muito grande. Ainda hoje deixei ele na quitanda, enquanto eu ia lá embaixo na cidade, e ele deixou a quitanda para ir na venda beber.

- Está bom, perdoa-lhe, disse eu.

- Pois não, nhonhô. Nhonhô manda, não pede.

(ASSIS, 1999, p. 151).

Limitado a simular, imitar, Prudêncio não alcança o estágio da dissimulação. $\mathrm{Na}$ condição de senhor "era livre, dispunha de si mesmo, dos braços, das pernas, podia trabalhar, folgar, dormir, desagrilhoado da antiga condição, agora é que ele se desbancava: comprou um escravo, e ia-lhe pagando, com alto juro, as quantias que de mim recebera. Vejam as subtilezas do maroto!". Repetindo a ação e a violência recebida, ele reforça a tradição senhor/escravo e a sociedade escravocrata, apresentando-se como um ridículo repetidor com uma fantasia desconjuntada de senhor. Ações que a princípio até lembram as que foram tomadas pela próxima personagem a ser analisada.

\section{Vicente: o dissimulador}

As visitas do Dr. Valdez, narrativa vencedora do Prêmio Craveirinha de 2005, é o segundo romance de João Paulo Borges Constantino Coelho, publicado em 2004. O fato de o autor ser historiador marcará profundamente sua escrita. A narrativa trata, resumidamente, das relações entre duas senhoras, Sá Caetana e Sá Amélia, ambas mestiças, e de um de seus criados, Vicente, negro, enquanto agonizava o regime colonial do antigo império português. Ainda que a história gire em torno desse pequeno núcleo, há uma projeção para o macro. As minudências da vida das personagens estão em profunda relação de igualdade com ocorrências fundamentais para a história do país. As personagens caracterizam metonimicamente extratos da história moçambicana, ao passo que as duas senhoras representam o passado colonial e de exploração do negro, o rapaz/criado representa o futuro de Moçambique, ainda inseguro, incerto, sem saber que rumos tomaria depois da incipiente "ausência" dos "senhores" coloniais portugueses. Projeção ainda maior pode ser feita quando se deixa de pensar somente no espaço de Moçambique e se 
amplia este território para todo o continente africano pós-colonizado e também para o continente americano dos países ex-colônias europeias.

A sociedade colonial de Moçambique não é muito diferente de outras colônias portuguesas inclusive do Brasil. Os valores culturais e morais são semelhantes. Também se valoriza mais a aparência do que qualquer outra coisa. Conhecer pessoas importantes e se fazer conhecido e respeitado por elas é passo fundamental para quem deseja estabelecer-se como senhor ou senhora:

Um dia em que o major foi de visita a casa de Ana Bessa levou Araújo consigo. 'Tem que conhecer novas pessoas, homem", dizia, "pois é aí que está a chave do sucesso nesta merda de terra. Falar com este porque conhece aquele, e por aí fora até conseguirmos o que queremos!" (COELHO, 2004, p. 28).

Também, da mesma forma, os casamentos são arranjados de acordo com interesses pessoais, em que o que conta como mais forte é o interesse financeiro ou de influências - o objetivo quase sempre era a ascenção social, o casamento por conveniência, como todas as demais relações estabelecidas neste contexto. É assim que se dá o casamento entre Araújo e Caetana, um acordo firmado para atender interesses tão diversos de ambos:

Deram-se bem pelas mais variadas razões, principalmente porque a nenhum deles fazia falta uma grande paixão. Araújo queria assentar e buscava na rapariga quem lhe tomasse conta da casa; estava mesmo disposto a conceder-lhe inteira jurisdição sobre esse espaço. Ele tomaria conta do coqueiral, então ainda em projecto.

Caetana por seu turno, buscava nele a segurança.

(COELHO, 2004, p. 28)

A elite colonial, ou seja, a sociedades colonizadas por portugueses e também espanhois em espaços americanos e africanos, é marcada pela doblez, dois modos de vida que não conseguindo se fundir, coexistem alternando de um para outro, obedecendo as conveniências de cada situação. Essa coexistência pode ser observada tanto na realidade colonial brasileira quanto na moçambicana.

Essa dupla personalidade, pregar alguma coisa e fazer outra é característica crucial para compreender as atitudes dos que vivem neste espaço: "Viviam, por isso, duas vidas, como se duas naturezas coabitassem num corpo só: uma ainda embaraçada, a outra já voraz, insaciável." (COELHO, 2004, p. 35). Na verdade, todos ou estão simulando ou dissimulando. As ideias não estavam fora-de-lugar, 
elas eram criadas e recriadas em espaço diferente - assim como as pessoas precisavam também sofriam mutações físicas e morais. "Naquele fim de mundo a que se afeiçoavam, iam os estrangeiros perdendo aos poucos a noção da disciplina, desenvolvendo eflúvios libidinosos em relação à comida, ao sexo, à natureza". (COELHO, 2004, p. 35). Em terras diferentes os colonizadores, no primeiro momento, tentavam manter-se alienados àquele novo espaço. Debatiam-se em vão contra a cultura, o clima, a vegetação local. Por fim, se transformavam - e não por influências da própria terra nova em que passavam a viver e sim por conveniência, caprichos que agora poderiam se dar o luxo de ter - explorando física e culturalmente o espaço e os povos autóctones.

Debatiam-se construindo argumentos só para si como uma frágil muralha onde todos os dias se iam abrindo pequenas brechas. A moral, outrora tão imensa que parecera universal, era agora exígua neste novo e amplo espaço, quase infinito. A justiça deixava de ser cega, ganhava argutos olhos e movediças fundações. Até a estética se deixava enredar nos labirínticos caminhos da novidade, desprezando conquistas pacientemente realizadas e reconhecidas para se maravilhar pelo caminho, pelo diferente. (COELHO, 2004, p. 35).

\section{Exatamente assim era Cotrim, personagem de Memórias póstumas de Brás} Cubas que, segundo o narrador, possuía "um carácter ferozmente honrado", tinha muito amor pelos filhos, era até mesmo "tesoureiro de uma confraria e irmão de várias irmandades, e até irmão remido de uma destas". Porém, com frequência enviava os escravos para o calabouço e estes desciam sangrando - contudo não havia problema, pois fazia isto somente com aqueles que eram "perversos" ou fujões. Também eram assim o padre Jacinto, que, "supremo guardião da moral", pregava as regras e normas da igreja e aparentemente apresentando "brio profissinoal", se permitia "regulares escapadelas noturnas em busca de meninas da terra" e o Dr. Valdez, que, apesar de alertar seus pacientes dos riscos do colesterol, não abdicava para si o prazer de devorar um "gordo e amarelo pacote de manteiga" - prazer "que o fez partir sem certidão de óbito, uma vez que era o único médico da vila e de toda a região, não tendo ficado ninguém depois dele para a passar". (COELHO, 2004, p. 37).

Nesse espaço de fingimento, de aparências, em que todos estão ou simulando ou dissimulando, caberá ao criado aprender, como condição de sobrevivência, a fazer o mesmo. Assim, Prudêncio aprende com o pai tal como seu pai, e antes deste o avô, também Cosme Paulino, foi um criado competente. Mas esta predisposição natural ainda não chegava: foi preciso que cada um deles tivesse 
aprendido a sua arte, encaixando-a na arte dos respectivos patrões. (COELHO, 2004, p. 38). A arte de servir é também a arte de simular.

A servidão é algo que é herdado passado para o DNA cultural - também o DNA físico/biológico possui influência sobre a vida das pessoas: “Assim, a cor de um indivíduo nunca é simplesmente uma cor, mas um enunciado repleto de conotações e interpretações articuladas socialmente, com um valor de verdade que estabelece marcas de poder, definindo lugares, funções e falas" (COELHO, 2004, p. 35) de criado para criado, patrão para patrão, de geração para geração.

De um lado, o signo da brancura, sinônimo do bem e do belo; do outro, o signo da negrura, metáfora do mal e do feio. (...) $\mathrm{O}$ discurso racista constrói, assim, uma escala gradativa, que elege, aleatoriamente, os matizes de uma tolerância possível, que, no íntimo, pretende mascarar a realidade de uma marginalização coletiva. $\mathrm{O}$ artifício linguístico revela-se, portanto, sintoma de uma prática racista que não discerne, apenas discrimina, pois, em todas as suas variações, os signos que designam o sujeito negro estão impregnados de um valor pejorativo mais ou menos ostensivo. (MARTINS, 1995, p. 38 - destaques da autora).

Assim se estabelecia o círculo vicioso, cada criado deixaria filhos que continuariam a servir e cada patrão deixaria para seus herdeiros o poder de mandar:

Sempre fiel ao patrão, fazendo como ele fazia, e antes de desaparecer com ele no meio das águas do Índico, deixou também o avô de Paulino, e bisavô de Vicente, um filho seu para que a relação entre os dois, patrão e criado, pudesse ter continuidade para além daquele definitivo percalço. (COELHO, 2004, p. 40).

É desta forma que Ana Bessa tem uma filha que herda a altivez do pai ao passo que o criado tem um menino (Cosme) "que herdava também a maneira de servir de seu pai”. A função e até mesmo o nome do criado fora escolhido pela patroa: "Ana Bessa quis que fosse seu mbwana e achou ter cara de Cosme, e por isso Cosme ficou". (COELHO, 2004, p. 41).

$\mathrm{O}$ ato de servir exige alterações profundas, até mesmo mudança de personalidade. Por isso, a aprendizagem ocorre de forma sistemática. Vicente era apenas uma criança e já recebia de forma dura os ensinamentos de seu pai. Seja observando o pai receber pancadas amarrado por ter "roubado" o açucar de seu patrão, seja observando a postura do pai. Desta maneira, o menino que 
corria e sorria livremente adquire o aspecto de sombra, simples objeto da casa ou mais uma das plantas existentes no coqueiral - fazendo-se assim invisível. É por isso que, dominando a arte, ele passa de simples menino encarregado de pequenos recados para criado "de pleno direito da mesma forma acontecera com seu pai (Cosme Paulino) que dando provas de ser um bom criado passou a servir no interior da casa.

Depois, aos poucos foi perdendo em gargalhadas o que ganhou em compenetração, os saltos que dava esmorecendo, assumindo o corpo a postura mais curvada de respeito. Observava como o pai servia pois chegaria um dia a sua vez. Cosme Paulino notava esse percurso atravessando o tempo e sorria intimamente, satisfeito e orgulhoso do seu fruto.(...) Mais tarde fez Vicente pequenos recados e finalmente, um dia, ascendeu a criado de pleno direito. Um criado sempre disponível, sempre ao serviço, e portanto sempre acompanhado, quase nunca só. (COELHO, 2004, p. 43).

Vicente é o criado da família. Seu pai também um criado, também fora seu avô um criado e assim por diante desde a chegada dos portugueses em Moçambique. Mais uma vez, também em Africa - um continente de distância -, o círculo vicioso se apresenta. Tal como as castas, talvez ainda mais rígida, a mobilidade social no Brasil escravocrata e no Moçambique colonial não existe. Viver na condição de criado é sobreviver. A sobrevivência só é possível por meio da estética da dissimulação.

Ser criado é não ter vontade própria e fazer o que lhe é ordenado. Por isso, que mesmo saindo de Ibo e passando a viver no ambiente urbano, Vicente é forçado a repetir aspectos de sua vida no meio rural. Nem mesmo o simples ato de assobiar durante o trabalho, para tornar mais leve o fardo da servidão, lhe é permitido:

- Acaba com o assobio, rapaz! Onde se viu um criado assobiar dentro de casa da patroa?!

- Sim senhora! - calava-se ele.

- Esta casa é mais pequena mas é como se fosse ainda a Casa Grande do Ibo, entendes? Haja respeito!

- Sim senhora! - repetia ele.

(COELHO, 2004, p. 23).

Poderia ter terminado nessa fase a história da perpetuação da servidão. Entretanto, a história de Moçambique mudou e com ela as histórias pessoais de 
cada um também foi alterada: Sá Caetana, Sá Amélia, Cosme Paulino, Vicente e todos os demais sofreram as alterações no novo contexto econômico e político do país. Mudança significativa teve a vida de Vicente que deixando de servir na imensidão das terra do Ibo, via-se agora em espaço reduzido de uma pequena habitação na cidade. Em espaços reduzidos as relações se estreitam e tornam-se mais complexas e tensas. Toda esta situação de mudança ajudou Vicente a ficar mais próximo das patroas e a aprender repetindo os gestos e apropriar-se da forma de ser, dos frames próprios de outra classe social. E por meio dessa aproximação surge a "máscara" do Dr. Valdez que Vicenta passa a encarnar: "- Amanhã vem visitar-nos o Dr. Valdez e eu vou queixar-me de ti, minha irmã! Vou dizer-lhe como te comportas! - disse". (COELHO, 2004, p. 33). Sá Caetana faz a promessa como um meio de acalmar a irmã e depois fica sem saber como cumpri-lá. Vicente, na tentativa de bem servir, se dispõe a ajudá-la fazendo-se passar pelo ilustre doutor:

Horas em que foi construindo um doutor que era velho doutor que ele via passar quando criança, caminhando pelas ruas do Ibo imponente e altivo como um navio que sulcasse as águas na distante linha do horizonte. E era também uma figura alimentada pelas imagens todas juntas de todos os brancos que Vicente foi vendo passar ao longo da vida, sempre ligeiramente irritadiços e carrancudos ou rindo desbridamente quando o faziam, sempre muito imprevisíveis, vagamente ameaçadores. Sempre, também, figuras que despertavam uma certa e inexplicável hilaridade. (COELHO, 2004, p. 48).

A simulação precisava ser perfeita e Vicente passou muito tempo ensaiando os gestos e questionando, buscando os modos de agir e de pensar do velho doutor. "Como pensa um branco? Como sente um branco? Como age um homem branco? Fica evidente a relação que se faz presente no livro de Leda M. Martins:

Submetido secularmente a um processo de reificação, ao negro só foi possível esconder-se sob máscaras brancas - Fanon se faz aqui referência obrigatória - , escamoteando seus símbolos e crenças sob o tecido cultural a ele imposto pelo outro. (MARTINS, 1995, p. 15).

Já mascarado, passeou-se na escuridão do quarto para lá e para cá, procurando entrar "na pele do Dr. Valdez". (Coelho, 2004, p. 48). Buscou nas lembranças características daquele homem branco que vira na sua infância: 
a mania de piscar muito os olhos dando a ideia de saber o que se diz, tossir ligeiramente depois de falar deixando sublinhado o que se diz, espetar o dedo indicador, espalhar pausas entre as frases simulando reflexão. Até que, por fim, estava pronto, seguro para representar o papel: “ - Sá Amélia! Há quanto tempo! - retorquiu Vicente com um timbre estudado, tão grave e soando falso que Sá Caetana, escondida ainda no corredor, mal pôde conter o riso". (COELHO, 2004, p. 49).

Sá Amélia observando a cena sorrateiramente não identificava na figura de Vicente o Dr. Valdez de sua lembrança. Entretanto, ainda assim, reconhecendo naquela figura uma representação falsa e mal construída, não a observava de forma inerte e perguntava-se: "Meu Deus! Será que é assim que eu guardo Valdez na lembrança sem o saber? Ou será que é assim que Vicente nos vê a nós, os brancos todos?"(COELHO, 2004, p. 59).

O rapaz aproveita-se para viver aqueles poucos minutos como branco. Senta-se no sofá, lugar que até então lhe fora negado. Tudo se inicia simulando as atitudes do Dr. Valdez. Contudo, com o tempo, a máscara fixa-se em sua pele e nem ele nem mesmo o doutor representado são os mesmos. O rapaz, percebe Sá Amélia, que parecia tão obediente como o pai, agora estava diferente.

Dentro da fantasia daquele velho doutor vivia um Vicente que já não era o mesmo Vicente/criado do passado. É na cena do açucar que isto fica claro. O Dr. Valdez representado pelo rapaz se nega o tomar o chá com açucar, trauma de sua infância provocado pelo episódio da surra recebida por seu pai e que ficara guardado em sua lembrança.

A primeira descoberta que faz o criado nos momentos de representação do médico é com relação ao poder das palavras: "E Vicente alegra-se com a descoberta, tanto esta como a outra, a de que as palavras têm a ver com as coisas que querem significar". (COELHO, 2004, p. 78). E assim, aos poucos, os papeis de imitador e imitado se invertem, pois há muito mais de Vicente no falso Dr. Valdez: "Aos poucos acabava sendo o Dr. Valdez que imitava Vicente e não o contrário". (COELHO, 2004, p. 110).

Cada sociedade tem seu regime de verdade, sua "política geral" de verdade, isto é, os tipos de discurso que ela acolhe e faz funcionar como verdadeiros; os mecanismos e as instâncias que permitem distinguir os enunciados verdadeiros dos falsos, a maneira como se sancionam uns e outros; as técnicas e os procedimentos que são valorizados para a obtenção da verdade; o estatuto daqueles que têm o encargo de dizer o que funciona como verdadeiro. (MARTINS, 1995, p. 35). 
É no momento em que passa a utilizar a máscara Mapiko que este "miúdo malandro" evolui na técnica da dissimulação e abandona ainda mais o processo de simulação/imitação inicial. Máscara esta que, segundo ele mesmo diz, já trazia dentro de si desde o momento em que observa o ritual de iniciação na aldeia. A principal característica dessa máscara de elmo é a capacidade de dissimular, fingir e enganar. A dificuldade de ver os olhos daquele que a utiliza intensifica ainda mais o processo de enganação. $\mathrm{O}$ fato de esconder os olhos favorece a atitude dissimuladora do criado que se sente protegido longe do olhar de autoridade de Sá Caetana. Vicente "Queria mudar mas não sabia como; queria partir mas eram poderosas as forças que o retinham no mesmo lugar" (COELHO, 2004. p. 135), queria romper com o círculo vicioso que o impelia para a servidão, para a ausência de voz. A solução encontrada por ela é a utilização de máscaras (Dr. Valdez, máscara-elmo):

A máscara-elmo do dançarino dissimula e mente: quando ele se inclina para a frente parece estar direita, quando ele se põe direito fica sobranceira e altiva, virada para cima. Onde deviam estar os olhos, que os circunstantes procuram avidamente para assim conhecerem o seu segredo, há apenas dois buracos negros, dois vazios que o dançarino tem na testa para os enganar. (COELHO, 2004, p. 143).

É voltando à tradição que Vicente encontra forças para vencer a situação de humilhação em que vive. Entretanto, esse retorno à tradição não se dá para repetir essa tradição e sim para transformá-la, renegar e reafirmar antigas tradições e assim romper com a tradição de servidão - "Viver é sempre fazer diferente, é respeitar a tradição e renegá-la". (COELHO, 2004. p. 145):

A sua grotesca dança é feita de passos desconexos e gestos teatrais. Finge que é bicho, finge que é branco (fingiria ser o Dr. Valdez se acaso o conhecesse), finge que é coxo, finge que é demente. (COELHO, 2004, p. 144).

Dessa forma, ele passa pelos três modos estereotipados com que o negro era visto. E quem anuncia esses estados são as próprias patroas, Sá Amélia e Sá Caetana, nas observações que fazem do criado, tal como aborda Leda M. Martins em seu livro A cena em sombras: o estágio de escravo fiel ou criado fiel; o de personagem caricatural, quando começa a imitar o Dr. Valdez; e o de elemento pernicioso quando começa a dissimular. Apossando-se dessa tradição, Vicente consegue livrar-se do ishima repassado para ele pelo próprio pai, consegue também 
livrar-se dos trejeitos do velho do Dr. Valdez e dos brancos, ou dos patrões de forma geral, para somente assim encontrar sua própria identidade, sua própria voz:

Vai-te, Dr. Valdez. Desenterrei-te de um buraco qualquer de onde não esperavas sair nunca mais. Tirei-te do esquecimento, trouxe-te para a cidade a visitar velhas amigas. Arejei-te as roupas, cofiei-te os bigodes, aqueci-te a alma. Reconstruí pacientemente a tua imagem, os trejeitos de que já ninguém se lembrava. Trouxe verosimilhança ao teu fantasma. Tornei a tua presença desejada por outros. Com que intensidade te imaginei quando todos te haviam já esquecido! Para receber o quê em troca? Meia dúzia de tostões com que pagar uma cerveja aos amigos, meia duzia de tostões atirados para o chão para que eu me vergasse a apanhá-los. (COELHO, 2004, p. 165).

\begin{abstract}
The purpose of this article is to work with the concept of aesthetics of concealment in a theoretical and practical approach. The chacters of two novels are compared: Prudêncio from Machado de Assis's Epitaph of a Small Winner and Vicente from João Paulo Borges Coelho's As visitas do Dr. Valdez. Two theoretical texts are more exploited, the essay Can the subaltern speak?, by Gayagri C. Spivak and Leda Maria Martin's A cena em sombras.
\end{abstract}

Keywords: African-brazilian literature. Subalternity. Aesthetics of dissimulation.

Referências

ASSIS, Machado de. Memórias póstumas de Brás Cubas. Belo Horizonte: Autêntica, 1999.

COELHO, João Paulo Borges. As visitas do Dr. Valdez. Lisboa: Caminho, 2004.

FOUCAULT, Michel. História da sexualidade 2: o uso dos prazeres. Rio de Janeiro: Graal, 1984.

MARTINS, Leda Maria. A cena em sombras. São Paulo: Perspectiva, 1995.

PAZ, Octavio. El laberinto de la soledad. Postdata. Vuelta a El laberinto de la soledad. México. Fondo de Cultura Económica, 2000.

REYES, Alfonso. Obra completa. México: Fondo de Cultura Económica, 1959.

SPIVAK, Gayatri Chakravorty. Pode o subalterno falar? Tradução de Sandra Regina Goulart Almeida, Andrpe Pereira e Marcos Pereira Feitosa. Belo Horizonte: Editora UFMG, 2010. 